\title{
PENGARUH SISTEM INFORMASI MANAJEMEN DAN CUSTOMER VALUE TERHADAP REPUTASI UNIVERSITAS SWASTA DI KOTA BATAM
}

\author{
Nur Elfi Husda dan Sadwianto Utama Putra \\ Prodi Manajemen, Fakultas Ekonomi \\ Universitas Putera Batam, Indonesia \\ nurelfi.upb@gmail.com \\ utamaptr1107@gmail.com
}

\begin{abstract}
ABSTRAK
Tujuan dari penelitian ini adalah untuk mengetahui pengaruh Sistem Informasi Manajemen dan customer value terhadap reputasi Universitas swasta di Kota Batam. Populasi penelitian adalah mahasiswa Universitas swasta pada program studi Manajemen yang mempunyai akreditasi B di kota Batam. Teknik analisa data yang digunakan dalam menjelaskan fenomena dalam penelitian ini adalah Structural Equation Modeling (SEM). Hasil penelitian menunjukan bahwa semakin baik Sistem Informasi Manajemen akan semakin meningkatkan penilaian mahasiswa terhadap Universitas, demikian juga penilaian mahasiswa terhadap reputasi universitas, namun baik atau buruknya Sistem Informasi Manajemen tidak memengaruhi tinggi rendahnya reputasi universitas. Semakin baik Sistem Informasi Manajemen, akan semakin meningkatkan reputasi universitas jika penilaian mahasiswa terhadap universitas juga baik.
\end{abstract}

Kata Kunci: Sistem Informasi Manajemen, customer value, reputasi perguruan tinggi swasta

\section{PENDAHULUAN}

\begin{abstract}
Banyak calon mahasiswa yang memilih perguruan tinggi negeri karena alasan lebih murah, lebih berkualitas, sementara kursi yang disediakan di perguruan tinggi negeri sangat terbatas, pilihan lain bagi calon mahasiswa adalah perguruan tinggi swasta. Namun tidak sedikit perguruan tinggi swasta yang juga berkualitas baik dari sisi sumber daya manusia maupun fasilitas yang diberikan.
\end{abstract}

Data dari pangkalan data perguruan tinggi (forlap.dikti.go.id) pada tahun 2015 bahwa jumlah mahasiswa yang terdaftar adalah 4.553.396 dimana jumlah mahasiswa yang terdaftar di Perguruan Tinggi Negeri hanya 1.215 .069 atau $26.68 \%$ dari jumlah seluruh mahasiswa yang terdaftar pada pangkalan data Direktorat perguruan tinggi. Dari gambaran tersebut sebagian besar mahasiswa adalah mahasiswa Perguruan Tinggi Swasta. Menjamurnya perguruan tinggi swasta yang menawarkan keunggulan dan kualitas yang baik merupakan tantangan bagi perguruan-perguruan tinggi swasta 
untuk memenangkan persaingan dan upayanya untuk merekrut calon mahasiswa. Perguruan tinggi swasta juga perlu mengidentifiasi factorfaktor yang menjadi pertimbangan seorang calon mahasiswa memilih perguruan tinggi swasta. Reputasi perguruan tinggi swasta akan memperbesar kemungkinan calon mahasiswa memimilih perguruan tinggi tersebut.

Menurut Badan Akreditasi Nasional Perguruan Tinggi (BANPT) salah satu indikator dari reputasi perguruan tinggi adalah nilai akreditasi program studi yang didapat perguruan tinggi tersebut. Semakin baik akreditasinya maka akan semakin baik reputasi perguruan tinggi di mata masyarakat. Program studi dengan peminat terbesar adalah program studi Manajemen dimana secara keseluruhan selalu mengalami peningkatan jumlah mahasiswa dari tahun ke tahun, namun ada juga beberapa perguruan tinggi yang mengalami penurunan jumlah mahasiswa. Pengelola perguruan tinggi harus mengetahui apakah kualitas layanan dan kemudahan yang diberikan sudah memenuhi standar perguruan tinggi sesuai dengan keinginan mahasiswa atau tidak. Bahkan masyarakat seringkali bersedia membayar lebih mahal atas biaya studi pada perguruan tinggi tertentu yang dinilai memiliki reputasi baik dan memuaskan kebutuhan mahasiswa.

Konsumen yang memakai barang atau jasa yang disediakan tentu menginginkan barang atau jasa yang berkualitas sebelum memutuskan untuk membeli atau tidak. Menurut (Mansoor \& Jalal, 2011) Konsumen adalah elemen paling dasar bagi setiap organisasi bisnis, kerenanya perilaku mereka juga menjadi penting bagi pemasaran dan peningkatan pendapatan organisasi. Sementara menurut (Hasan, 2008:170) Agar dapat sukses dalam persaingan, maka organisasi harus berusaha menciptakan dan mempertahankan konsumen dengan cara menghasilkan dan menyampaikan produk yang diinginkan konsumen dengan harga yang layak (reasonable). Oleh karena itu setiap pemasar harus memahami perilaku konsumen. Kelangsungan hidup organisasi sangat ditentukan oleh konsumen, baik konsumen akhir maupun konsumen industri.

Mengukur kualitas layanan (service quality) lebih sulit daripada mengukur kualitas produk karena banyak unsur subjektif yang melekat pada jasa. rendahnya kualitas dan kegagalan kualitas antara produk dan jasa juga berbeda. Produk sering gagal karena kegagalan bahan baku dan bahan lainnya. Kegagalan produk juga bisa disebabkan karena organisasi tidak memproduksi sesuai spesifikasi. Kualitas jasa yang rendah langsung disebabkan karena perilaku atau sikap organisasi yang berupa ketiadaan kepemimpinan, kepedulian, atau rasa hormat. Salah satu pendekatan kualitas jasa yang banyak digunakan sebagai acuan dalam riset pemasaran adalah model SERVQUAL (Service Quality) yang dikembangkan Zeithaml, Berry, dan Parasuraman. Model SERVQUAL diterapkan dengan melakukan perbandingan terhadap dua faktor utama yang memengaruhi kualitas jasa, yaitu persepsi konsumen atas jasa nyata yang diterima (perceived service) dan persepsi konsumen atas 
jasa yang sesungguhnya diharapkan (expected service), apabila kualitas jasa yang diterima lebih tinggi dari kualitas jasa yang diharapkan, jasa dapat dikatakan berkualitas, demikian sebaliknya. Jadi kualitas jasa dapat didefinisikan sebagai "seberapa jauh perbedaan antara kenyataan dan harapan konsumen atas layanan yang diterima" (Parasuraman, Zeithaml, \& Berry, 1988).

dalam $\begin{gathered}\text { Selain dari kualitas layanan, } \\ \text { pemasaran }\end{gathered}$
mengidentifikasi segmen pasar, orang atau badan yang menawarkan barang atau jasanya kepada membeli lalu memutuskan segmen mana yang memberikan peluang terbesar, segmen inilah yang akan menjadi pasar sasarannya. Untuk setiap segmen, organisasi mengembangkan suatu penawaran pasar yang diposisikannya dalam benak pembeli sebagai keuntungan utama. Menurut Kotler \& Keller, (2008) penawaran akan berhasil jika memberikan nilai dan kepuasan kepada pelangan yang membeli produk tersebut. Nilai mencerminkan sejumlah manfaat, baik yang berwujud maupun yang tidak berwujud, dan biaya yang akan dipersepsikan oleh pelanggan.

Tujuan dari penelitian ini adalah untuk mengetahui (1) pengaruh kualitas layanan terhadap nilai konsumen (2) pengaruh kualitas layanan terhadap reputasi (3) pengaruh nilai konsumen terhadap reputasi dan (4) hubungan langsung dan tidak langsung kualitas layanan terhadap reputasi melalui nilai konsumen pada Universitas Swasta di Kota Batam.

\section{KERANGKA TEORITIS}

\section{Sistem Informasi Manajemen}

Menurut O'Brien \& Marakas (2014) Sistem Informasi Manajemen memberikan informasi dalam bentuk laporan dan tampilan kepada manajer dan banyak pelaku bisnis. Sementara sistem informasi di defensikan sebagai kombinasi terorganisasi apapun dari manusia, perangkat keras, perangkat lunak, jaringan komunikasi, sumber data, dan kebijakan serta prosedur yang terorganisasi yang menyimpan dan, mengambil, mengubah dan memisahkan informasi dalam sebuah organisasi.

\section{Sutanta}

menyatakan bahwa sistem informasi manajemen dapat didefinisikan sebagai sekumpulan subsistem yang saling berhubungan, berkumpul bersama-sama dan membentuk satu kesatuan, saling berinteraksi dan bekerjasama anatara bagian satu dengan yang lainnya dengan caracara tertentu untuk melakukan fungsi pengolahan data, menerima masukan (input) berupa data-data, kemudian mengolahnya (processing), dan menghasilkan keluaran (output) berupa informasi sebagai dasar bagi pengambilan keputusan yang berguna dan mempunyai nilai nyata yang dapat dirasakan akibatnya baik pada saat itu juga maupun di masa mendatang, mendukung kegiatan operasional, manajerial, dan strategis tersebut guna mencapai tujuan.

Laudon \& Laudon (2015) mendefinisikan sistem informasi sebagai serangkaian komponen yang saling berhubungan yang mengumpulkan (atau mendapatkan), memproses, menyimpan, mendistribusikan informasi untuk mendukung pengambilan keputusan 
dan pengawasan di dalam sebuah organisasi.

\section{Customer Value (Nilai Konsumen)}

Customer Value (Nilai konsumen) merupakan keseluruhan nilai konsumen tentang kegunaan suatu produk atau jasa yang berdasarakan pada persepsi tentang apa yang diterima dan apa yang diberikan (Zeithaml et al., 2009). Defenisi nilai konsumen merupakan selisih antara nilai yang diperoleh pelanggan dengan memiliki dan menggunakan suatu produk, dengan biaya yang dikeluarkan untuk memperoleh produk tersebut (Kotler \& Gary, 2012). customer value memberikan gambaran tentang pelanggan suatu perusahaan, apa yang diinginkan pelanggan, dan pelanggan percaya untuk memperoleh suatu produk atau jasa.

Dengan nilai konsumen, mengaitkan ikatan emosional yang terbentuk antara konsumen dan produsen setelah konsumen menggunakan suatu produk atau jasa penting yang diproduksi oleh produsen dan menemukan produk tersebut memberikan suatu tambahan nilai. (Too, Souchon, \& Thirkell, 2001) melihat perlunya lintas fungsional dalam sebuah perusahaan, yaitu pemasaran, operasi dan sumber daya manusia sebagai prasyarat dalam mengelola nilai konsumen.

Menurut Sweeney \& Soutar, (2001), dimensi nilai terdiri dari empat yaitu: (1) Emotional value yaitu Utilitas yang berasal dari perasaan atau afektif atau emosi positif yang ditimbulkan dari konsumsi produk, (2) Social value yaitu Utilitas yang didapat dari kemampuan produk untuk meningkatkan konsep diri-sosial pelanggan, (3) Quality atau performance value yaitu utilitas yang didapat dari produk karena reduksi biaya jangka pendek dan biaya jangka panjang, dan (4) Price atau value of money yaitu utilitas yang diperoleh dari persepsi terhadap kinerja yang diharapkan dari suatu produk atau jasa.

\section{Reputasi}

Reputasi adalah seperangkat keyakinan bersama tentang kemampuan perusahaan untuk memenuhi kepentingan berbagai stakeholder (Beheshtifar \& Korouki, 2012). Reputasi menjadi sangat penting karena potensi untuk menciptakan nilai dan sifat dari reputasi yang berupa intangible character sulit untuk ditiru oleh perusahaan lain. Perusahaan yang menjual perpaduan dari produk nyata (tangible product) dan jasa layanan (intangible product) adalah hotel. Produk yang ditawarkan diantaranya seperti kamar, makanan dan minuman, ruang pertemuan, sarana olah raga dan rekreasi, hiburan dan fasilitas lainnya merupakan produk nyata yang disediakan hotel, sedangkan produk layanan seperti keramahan, ketepatan, kenyamanan merupakan produk jasa layanan (intangible product) (Roberts \& Dowling, 2002).

Reputasi perusahaan menurut Miles \& Covin, (2000) adalah pandangan atau persepsi atas perusahaan oleh orang-orang baik yang berada didalam maupun diluar perusahaan. Pemerhati perusahaan adalah customer atau pelanggan perusahaan yaitu pengecer disamping yang lainnya adalah pemilik saham, masyarakat, bank dan partner kerja. 
Sementara menurut Barnett, Jermier, \& Lafferty, (2006) Reputasi perusahaan merupakan gabungan tentang perusahan yang di evaluasi berdasarkan efek dari aspek keuangan, sosial dan lingkungan dari perusahaan selama periode waktu tertentu.

Reputasi institusi sebagai aset berharga yang harus dijaga. Upaya menjaga reputasi ini dapat dilakukan bila suatu institusi memahami publisitas media terhadap institusi mereka. Berbagai metode dapat digunakan suatu institusi untuk melihat publisitas mereka, dan cara yang disajikan di atas pada dasarnya hanya merupakan salah satu dari sekian banyak cara dalam melakukan monitoring dan evaluasi terhadap publisitas institusi. (Prajarto, 2008)

\section{Kerangka Konsep Penelitian}

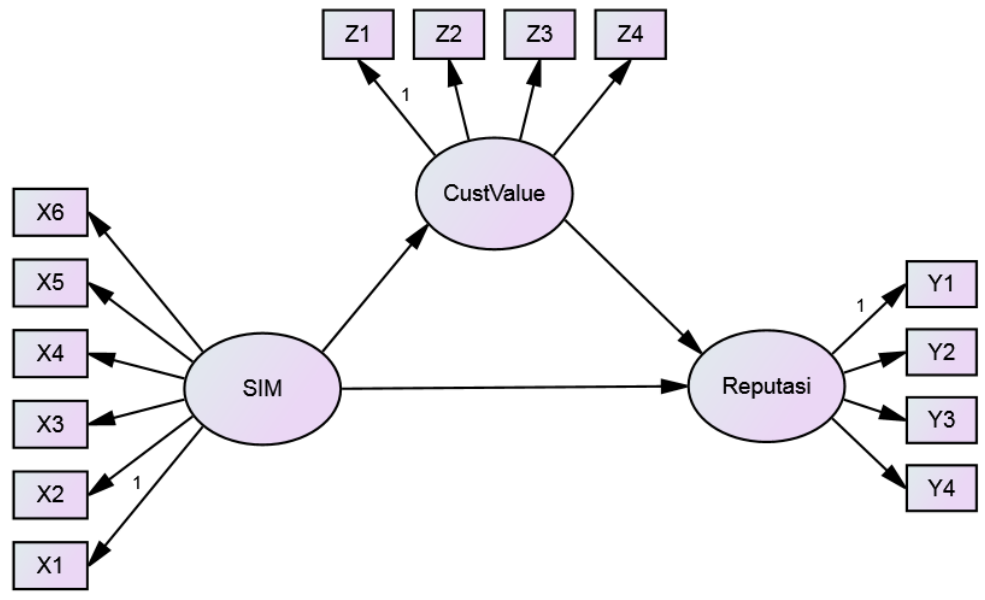

Gambar 1

Kerangka Konsep Penelitian

\section{Hipotesis}

H1 : Ada pengaruh yang signifikan antara Sistem Informasi Manajemen berpengaruh secara signifikan terhadap customer value

$\mathrm{H} 2$ : Ada pengaruh yang signifikan antara Sistem Informasi Manajemen berpengaruh secara signifikan terhadap reputasi

H3 : Ada pengaruh yang signifikan antara customer value berpengaruh secara signifikan terhadap reputasi
H4 : Diduga pengaruh langsung Sistem Informasi Manajemen lebih besar dari pada pengaruh tidak langsung Sistem Informasi Manajemen terhadap reputasi melalui customer value.

\section{METODE PENELITIAN}

Metode penelitian yang digunakan dalam penelitian ini adalah metode survey dengan Jenis penelitian ini adalah explanatory research, dimana dalam penelitian ini nantinya akan ditelaah mengenai hubungan kausalitas antar variabel- 
variabel melelaui pengujian hipotesis yang telah ditetapkan sebelumnya.

Populasi dari penelitian ini adalah mahasiswa program studi manajemen Universitas Swasta yang ada di Batam yang sudah menggunakan Sistem Informasi Akademik. Penelitian ini dilakukan pada mahasiswa universitas swasta yang ada di kota Batam yang sudah menggunakan Sistem Informasi Akademik dan memiliki web di Internet sebagai pendukung dalam pelayanan kepada mahasiswa. Kriteria sampel adalah mahasiswa program studi Manajemen yang mempunyai akreditasi program studi B karena dengan pertimbangan responden sudah memahami sistem informasi serta keseragaman akreditasi pada setiap Universitas. Sampel dengan menggunakan metode Proportionate stratified random sampling dimana populasi yang tidak homogen dan berstrata secara proporsional. Untuk populasi $=3,513$ yaitu jumlah mahasiswa program studi manajemen tahun 2015, maka sampel minimal menurut slovin adalah: 359 dibulatkan menjadi 360 .

Dalam penelitian ini instrumen yang digunakan adalah kuesioner, dimana nantinya kuesioner terdiri dari dua bagian yaitu data tentang identitas responden dan data yang berkaitan dengan variabel penelitian. Teknik analisa data yang digunakan dalam menjelaskan fenomena dalam penelitian ini adalah Structural Equation Modeling (SEM). Alat analisis ini dipilih karena dengan menggunakan metode SEM dapat diketahui pengaruh sebuah variabel baik langsung maupun tidak langsung terhadap variabel lain secara bersamaan.

\section{HASIL DAN PEMBAHASAN}

\section{Hasil Uji Validitas dan Reabilitas}

Hasil pengujian validitas dan reabilitas menunjukan signifikan (tabel 1) untuk seluruh indicator atau item pertanyaan, yang berarti indicator-indikator atau item-item pertanyaan untuk masing-masing variable yang terdapat dalam kuesioner telah memenuhi syarat validitas dan reabilitas. Dari korelasi product moment Pearson, diketahui bahwa semua item pertanyaan pada kuesioner mempunyai korelasi yang signifikan pada tingkat kesalahan sebesar 5\% $(* *<0.05)$, sehingga dapat dikatakan semua item pertanyaan adalah valid dan reliable sehingga dapat diolah lebih lanjut.

Tabel 1 : Hasil Uji Validitas dan Reabilitas Intrumen

\begin{tabular}{llllllll}
\hline \multirow{2}{*}{ Var } & \multicolumn{3}{l}{ Hasil Uji Validitas } & \multicolumn{3}{c}{ Hasil Uji Reabilitas } \\
& Item & Sig & Item & Sig & Ket & $\begin{array}{l}\text { aCronbac } \\
\text { h }\end{array}$ & Ket \\
\hline SIM & X1 & 0.000 & X4 & 0.000 & Item & & \\
& X2 & 0.000 & X5 & 0.000 & valid & 0.918 & Reliabel \\
& X3 & 0.000 & X6 & 0.000 & & & \\
Customer & Z1 & 0.000 & Z3 & 0.000 & Item & 0.869 & Reliabel \\
Value & & & & & valid & & \\
& Z2 & 0.000 & Z4 & 0.000 & Reliabel \\
Reputasi & Y1 & 0.000 & Y3 & 0.000 & Item & 0.915 & valid \\
& Y2 & 0.000 & Y4 & 0.000 & vali
\end{tabular}


Sumber: Hasil Olahan

\section{Uji Normalitas Data}

Kenormalan distribusi data dievaluasi dengan skewness dan kurtosis, variabel yang memiliki koefisien skewness dan kurtosis dengan critical ratio tidak lebih dari \pm 2.58 menunjukan distribusi tidak normal, dan sebaliknya berarti normal. Dari pengujian diketahui semua variabel manifest yang berjumlah 34 item pertanyaan memiliki critical ratio dibawah \pm 2.58, sehingga dinyatakan normal.

\section{Deskripsi Variabel Penelitian}

Berdasarkan hasil pengumpulan data dilapangan, maka diperoleh gambaran mengenai kondisi objek dari variable-variabel yang digunakan dalam penelitian ini, dimana variable-variabel tersebut adalah variable Sistem Informasi ManajemenCustomer Value, dan Reputasi. Dari hasil pengolahan data dari jawaban responden maka dapat ditentukan nilai masing-masing variabel sebagai dasar untuk mengidentifikasi bagaimana kecendrungan dan variasi tanggapan responden terhadap kuesioner yang telah diajukan untuk variabel penelitian.

\section{Variabel Sistem Informasi Manajemen \\ Variabel Sistem Informasi} Manajemen dievaluasi melalui enam dimensi yaitu: Pertama; Kualitas sistem, Kedua; kualitas informasi, Ketiga; Kualitas layanan, Keempat; penggunaan, Kelima; Kepuasan pengguna, dan Keenam; Manfaat bersih.

Hasil perhitungan deskriptif mendapatkan skor rata-rata Sistem
Informasi Manajemen dengan jumlah sampel sebesar 360 adalah 3.7408, perolehan ini dalam skala jawaban 1 sampai dengan 5 merupakan skor diantara $3.41-4.20$, namun kepuasan pengguna sistem informasi perlu lebih ditingkatkan lagi karena hampir pada skala sedang.

Dengan demikian perolehan 3.7408 dapat dibaca dengan baik, yang menjelaskan bahwa responden menilai Sistem Informasi Manajemen secara keseluruhan pada Universitas swasta di provinsi Kepulauan Riau dalam kondisi yang baik, dan masih berpotensi untuk ditingkatkan.

\section{Variabel Customer Value}

Variabel Customer Value dievaluasi melalui empat dimensi yaitu: Pertama; Emotional value, Kedua; Social value, Ketiga; Quality atau performance value, Keempat; Price atau value of money.

Hasil perhitungan deskriptif mendapatkan skor rata-rata Customer Value sebesar 3.5745, perolehan ini dalam skala jawaban 1 sampai dengan 5 yang menjelaskan bahwa responden menilai customer value pada Universitas swasta di provinsi Kepulauan Riau dalam kondisi yang baik, dan masih berpotensi untuk ditingkatkan terutama pada Quality atau performance value dengan nilai 3.460 .

\section{Variabel Reputasi}

Variabel Reputasi dievaluasi melalui empat dimensi yaitu: Pertama; Kredibilitas, Kedua; Kepercayaan, Ketiga; Kehandalan, Keempat; Nama baik. Hasil perhitungan deskriptif mendapatkan 
skor rata-rata Reputasi sebesar 3.6338, perolehan ini dalam skala jawaban 1 sampai dengan 5 mendekati yang menjelaskan bahwa responden menilai respon konsumen pada Universitas swasta di provinsi Kepulauan Riau dalam kondisi yang baik, dan masih berpotensi untuk ditingkatkan terutama pada dimensi kepercayaan

\section{Hasil Analisis Model Persamaan Struktural (SEM)}

Tujuan akhir dari SEM pada prinsipnya mendapatkan model structural. Model dikatakan baik bilamana pengembangan model hipotetik secara teoritis didukung oleh data empiric. Hasil dari analisis SEM dapat dilihat pada gambar 2

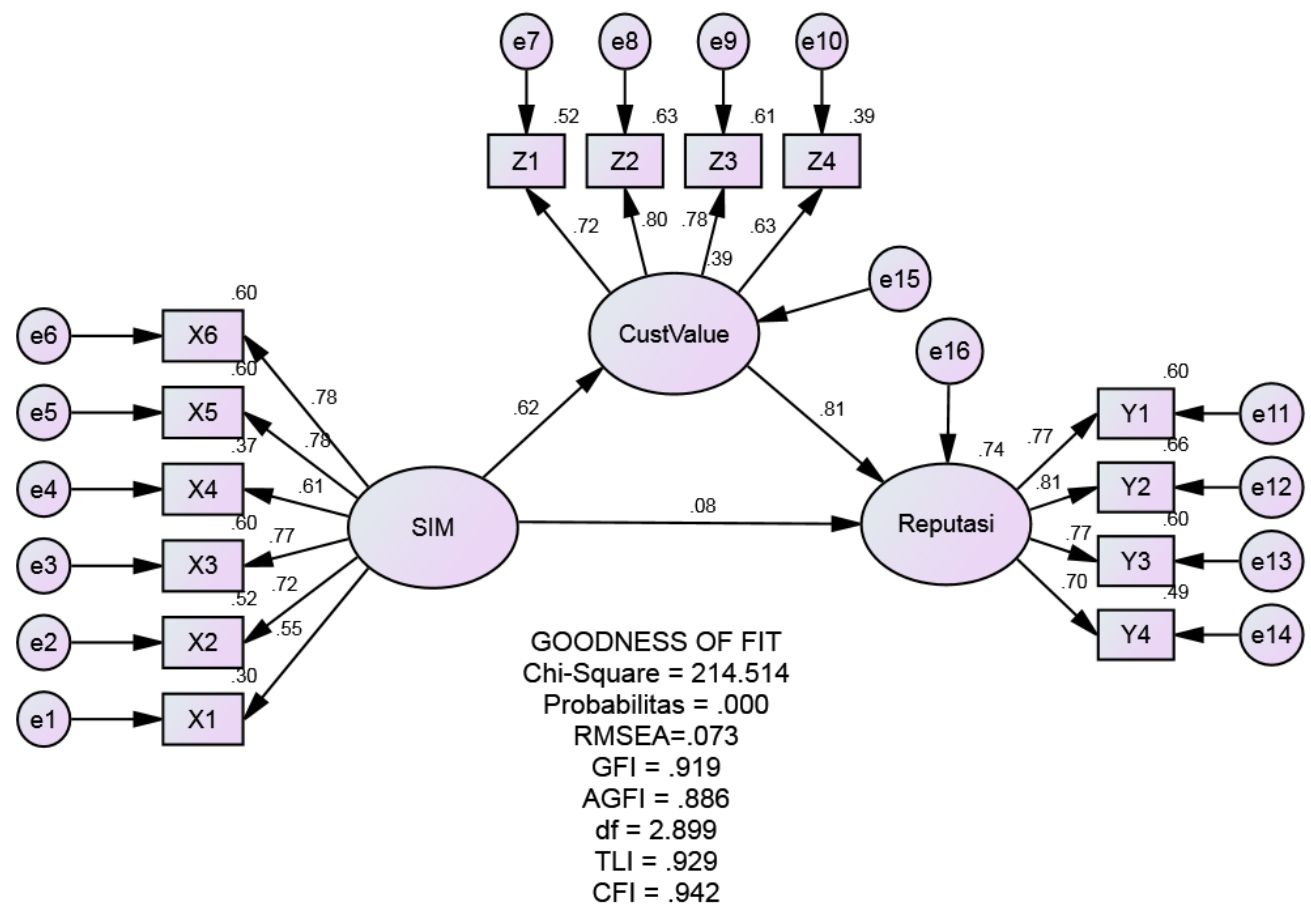

Gambar 2

Analisis Model Persamaan Struktural (SEM)

\section{Uji Model Penelitian}

Uji model pada penelitian ini menggunakan program AMOS versi 21 dapat dijelaskan beberapa hal sebagai berikut:

1. Terdapat delapan variabel laten pada model yang akan diuji yaitu: Variabel Sistem
Informasi Manajemen, customer value, dan reputasi.

2. Variabel Sistem Informasi Manajemen dibentuk oleh 6 indikator yaitu: kualitas sistem, kualitas informasi, kualitas pelayanan, penggunaan, kepuasan pengguna dan manfaat bersih. 
3. Variabel customer value dibentuk oleh empat indicator yaitu: emotional value, social value, quality atau performance value dan price atau value of money.

4. Variabel reputasi dibentuk oleh empat indicator yaitu: kredibilitas, kepercayaan, kehandalan dan nama baik.

Data penelitian ini diolah dengan menggunakan AMOS 21, sebelum mengkaji measurement model masing-masing variabel pada penelitian ini, akan dianalisis lebih dulu dimensi-dimensi dari indicator- indikator yang membentuk setiap variabel. Masing-masing loading factor pembentuk variabel pada penelitian ini dapat dijelaskan sebagai berikut:

\section{Sistem Informasi Manajemen}

Indikator dari variabel Sistem Informasi Manajemen terdiri dari kualitas sistem, kualitas informasi, kualitas pelayanan, penggunaan, kepuasan pengguna dan manfaat bersih. Hasil pengujian dengan metode confirmatory factor analysis (CFA) dapat dilihat pada gambar 3 berikut ini:

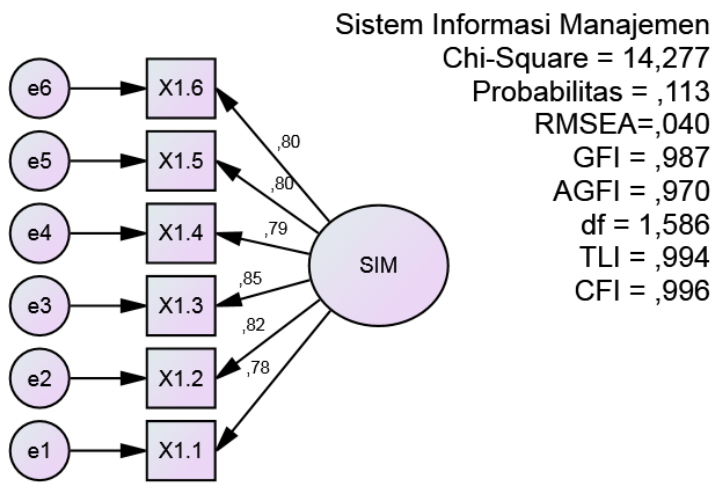

Gambar 3

Model Pengukuran variabel Sistem Informasi Manajemen

Dengan menggunakan analisis faktor untuk mencari faktor pembentuk variabel Sistem Informasi Manajemen, dapat diketahui bahwa faktor dominan yang membentuk Sistem Informasi Manajemen adalah kualitas pelayanan (0.848) yang artinya indicator ini mempunyai derajat paling besar dalam memengaruhi variabel Sistem Informasi Manajemen, sedangkan indikator paling rendah adalah kualitas sistem (0.776). akan tetapi secara keseluruhan semua indikator yang telah ada menunjukan signifikan, sehingga dapat dipergunakan semuanya sebagai dasar penelitian.

Berdasarkan hasil uji statistic dalam AMOS versi 21 maka didapat nilai dari CR (critical ratio) untuk setiap indikator pembentuk variabel sistem informasi manajemen lebih besar dari 2. Dengan demikian, maka keenam indikator tersebut merupakan indikator-indikator yang secara signifikan membentuk variabel sistem informasi manajemen. Kontribusi paling besar dalam membentuk sistem informasi manajemen adalah indikator kualitas 
layanan dari sistem informasi tersebut yang artinya bahwa responden lebih mengutamakan kualitas layanan dari sebuah sistem informasi yang diikuti dengan kualitas informasi, kepuasan pengguna, manfaat bersih, penggunaan (use) dan terakhir kualitas sistem.

\section{Customer Value}

Indikator dari variabel Customer Value terdiri dari emotional value, social value, quality atau performance value dan price atau value of money. Hasil pengujian dengan metode confirmatory factor analysis (CFA) dapat dilihat pada gambar 4 berikut ini:

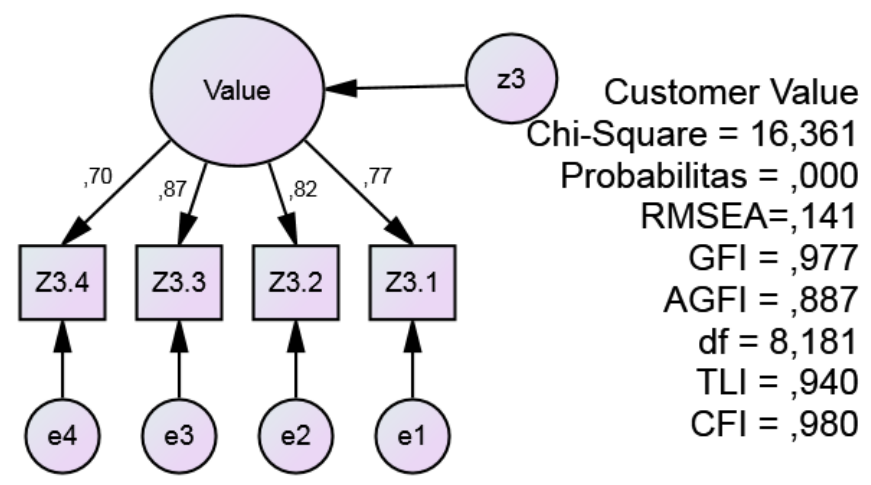

Gambar 4

Model Pengukuran variabel Customer Value

Dengan menggunakan analisis faktor untuk mencari faktor pembentuk variabel Customer Value, dapat diketahui bahwa faktor dominan yang membentuk Customer Value adalah Quality atau performance value (0.874) yang artinya indikator ini mempunyai derajat paling besar dalam memengaruhi variabel Customer Value, sedangkan indikator paling rendah adalah Price atau value of money (0.699). akan tetapi secara keseluruhan semua indikator yang telah ada menunjukan signifikan, sehingga dapat dipergunakan semuanya sebagai dasar penelitian.

Berdasarkan hasil uji statistic dalam AMOS versi 21 maka didapat nilai dari CR (critical ratio) untuk setiap indikator pembentuk variabel Customer Value lebih besar dari 2.
Dengan demikian, maka keempat indikator tersebut merupakan indikator-indikator yang secara signifikan membentuk variabel Customer Value. Kontribusi paling besar dalam membentuk Customer Value adalah indikator Quality atau performance value dari Customer Value tersebut yang artinya bahwa responden lebih mengutamakan Quality atau performance value dari Customer Value yang diikuti dengan Sosial Value, kemudian Emotinal Value, dan terakhir Price atau value of money.

\section{Reputasi}

Dengan menggunakan analisis faktor untuk mencari faktor pembentuk variabel reputasi, dapat diketahui bahwa faktor dominan yang membentuk reputasi adalah kepercayaan (0.900) yang artinya 
indikator ini mempunyai derajat paling besar dalam memengaruhi variabel reputasi, sedangkan indikator paling rendah adalah nama baik (0.801). akan tetapi secara keseluruhan semua indikator yang telah ada menunjukan signifikan, sehingga dapat dipergunakan semuanya sebagai dasar penelitian.
Indikator dari variabel reputasi terdiri dari kredibilitas, kepercayaan, kehandalan dan nama baik. Hasil pengujian dengan metode confirmatory factor analysis (CFA) dapat dilihat pada gambar 5 berikut ini:
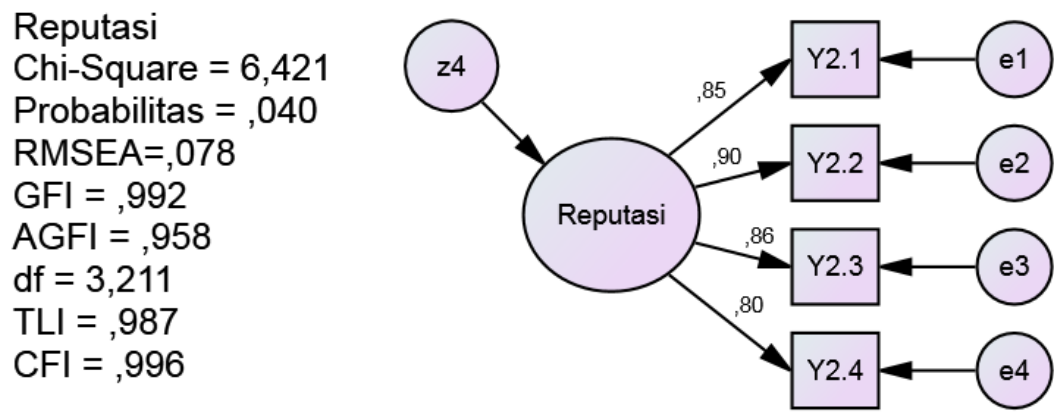

Gambar 5

Model Pengukuran variabel Reputasi

Berdasarkan hasil uji statistic dalam AMOS versi 21 maka didapat nilai dari CR (critical ratio) untuk setiap indikator pembentuk variabel reputasi lebih besar dari 2. Dengan demikian, maka keempat indikator tersebut merupakan indikatorindikator yang secara signifikan membentuk variabel reputasi. Kontribusi paling besar dalam membentuk reputasi adalah indikator kepercayaan dari reputasi tersebut yang artinya bahwa responden lebih mengutamakan kepercayaan dari reputasi yang diikuti dengan kehandalan, kemudian kredibilitas, dan terakhir nama baik.

\section{Hasil Pengujian Hipotesis Penelitian}

Untuk mengetahui diterima dan ditolaknya hipotesis penelitian digunakan parameter yang berdasar pada derajat toleransi kesalahan $\alpha=$ $5 \%(0,05)$ sehingga kriteria nilai $\mathrm{p}=$ $<0,05$, serta dengan batasan C.R sebesar 1,96. Nilai-nilai tersebut digunakan untuk pengambilan keputusan dalam menjawab hipotesis penelitian. Intepretasi hubungan masing-masing variabel yang dihipotesiskan, beserta koefisiennya dapat dilihat pada tabel 2

Tabel 2: Hasi Uji Signifikan Antar Variabel

\begin{tabular}{|c|c|c|c|c|c|c|}
\hline Hipotesis & & Estimate & S.E. & C.R. & $\mathrm{P}$ & Kesimpulan \\
\hline SIM & $\rightarrow$ CustValue & .892 & .116 & 7.714 & 0.000 & Signifikan \\
\hline CustValue & $\rightarrow$ Reputasi & .858 & .086 & 9.982 & 0.000 & Signifikan \\
\hline SIM & $\rightarrow$ Reputasi & .126 & .094 & 1.342 & 0.180 & Tidak Signifikan \\
\hline
\end{tabular}




\section{Analisis dan Pembahasan}

\section{Pengaruh Sistem Informasi Manajemen Terhadap Customer Value}

Temuan dalam penelitian ini membuktikan bahwa Sistem Informasi mempunyai pengaruh signifikan terhadap customer value yaitu sebesar 0.892 dan bersifat positif. Nilai C.R > 1.96 dan nilai $p$ $0.000<0.05$ dengan demikian hipotesis yang menyatakan Sistem Informasi Manajemen berpengaruh terhadap customer value terbukti signifikan.

\section{Hasil Confirmatory Factor} Analysis (CFA) menunjukan bahwa variabel Sistem Informasi Manajemen lebih ditentukan dimensi (indikator) yang memiliki loading factor besar, yaitu kepuasan pengguna $\quad(X 5=1.847), \quad$ kualitas pelayanan $(X 3=1.619)$, manfaat bersih $\quad(\mathrm{X} 6=1.590), \quad$ kualitas informasi $(\mathrm{X} 2=1.536)$, penggunaan $(\mathrm{X} 4=1.116)$ dan kualitas sistem $(\mathrm{X} 1=1.000)$.

Temuan ini sejalan dengan penelitian (Chang \& Wang, 2011) bahwa kualitas desain web berpengaruh terhadap nilai yang dirasakan konsumen serta penelitian (Yieh et al., 2012) yang menyatakan bahwa penerimaan teknologi informasi berpengaruh signifikan terhadap nilai yang dirasakan konsumen.

\section{Pengaruh Customer Value Terhadap Reputasi}

Temuan dalam penelitian ini menyatakan bahwa customer value berpengaruh secara signifikan terhadap reputasi yaitu sebesar 0.858 dan bersifat positif. Nilai C.R > 1.96 dan nilai p $0.000<0.05$ dengan demikian hipotesis yang menyatakan bahwa customer value berpengaruh terhadap reputasi terbukti.

Hasil CFA menunjukan bahwa variabel customer value lebih ditentukan dimensi (indikator) yang memiliki loading factor besar, yaitu quality atau performance value $(\mathrm{Z} 3=1.224)$, social value $(\mathrm{Z} 2=1.184)$, emotional value $(\mathrm{Z} 1=1.000)$, price atau value of money $(\mathrm{Z} 4=0.945)$

Temuan ini sejalan dengan penelitian yang dilakukan oleh (Jouzaryan et al., 2015) yang menyatakan bahwa Customer Value berpengaruh positif terhadap reputasi pada Refeh Bank

\section{Pengaruh Sistem Informasi Manajemen Terhadap Reputasi}

Temuan dalam penelitian ini menyatakan bahwa Sistem Informasi Manajemen tidak berpengaruh secara signifikan terhadap reputasi hanya 0.126 dan dilihat dari nilai C.R $(1.342)<1.96$ dan nilai p $0.18>0.05$ dengan demikian hipotesis yang menyatakan bahwa Sistem Informasi Manajemen berpengaruh terhadap reputasi tidak terbukti.

Hasil CFA menunjukan bahwa variabel reputasi lebih ditentukan dimensi (indikator) yang memiliki loading factor besar, yaitu kepercayaan (Y2=1.041), kredibilitas (Y1=1.000), kehandalan ( $\mathrm{Y} 3=0.966)$, nama baik (Y4=0.805)

Hasil penelitian ini tidak sesuai dengan penelitian yang dilakukan oleh (Nathalia, 2012) yang menyatakan bahwa kualitas web 
mempengaruhi reputasi hotel. Temuan penelitian ini menunjukan bahwa Sistem Informasi Manajemen tidak berpengaruh terhadap reputasi, dapat dijelaskan bahwa meskipun Sistem Informasi Manajemen pada suatu Universitas sudah baik, namun belum tentu mahasiswa menilai reputasi Universitas berdasarkan Sistem Informasi Manajemen yang dimiliki, namun juga berdasarkan rasa percaya masyarakat terhadap kredibilitas Universitas, kelebihan universitas dibandingkan dengan kampus lain serta nama baik kampus yang dimata masyarakat.

\section{Pengaruh Langsung dan Tidak Langsung Sistem Informasi Manajemen Terhadap Reputasi melalui Customer Value}

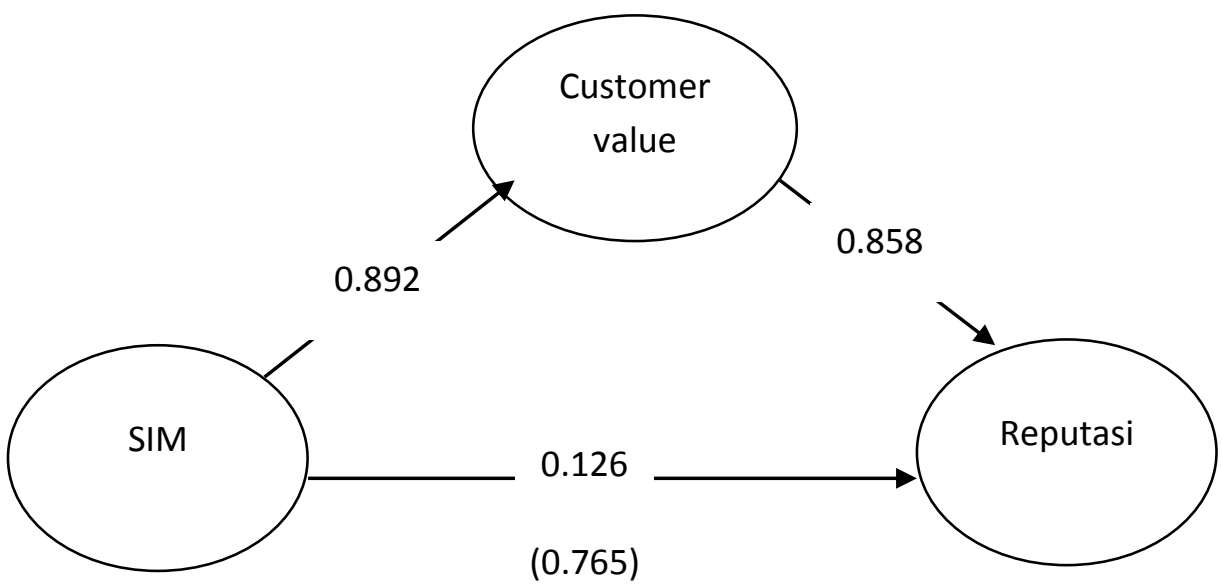

Gambar 6

Pengaruh Langsung dan Tidak Langsung SIM terhadap Reputasi Melalui Customer Value

Berdasarkan hasil analisis pengaruh langsung tidak langsung Sistem Informasi Manajemen (X) terhadap reputasi (Y) diperoleh pengaruh 0.126 sementara pengaruh tidak langsung sebesar 0.765 . Karena pengaruh tidak langsung antara Sistem Informasi Manajemen terhadap reputasi melalui customer value lebih besar dari pengaruh langsung Sistem Informasi Manajemen terhadap customer value, artinya semakin baik Sistem Informasi Manajemen yang dipunyai Universitas akan semakin meningkatkan reputasi Universitas jika nilai pelanggan juga tinggi.

\section{SIMPULAN}

\section{Simpulan}

Dari hasil analisis dan pengujian hipotesis yang telah dilakukan sebelumnya maka penelitian ini dapat ditarik kesimpulan sebagai berikut:

1. Sistem Informasi Manajemen berpengaruh secara signifikan terhadap customer value dalam arti semakin baik Sistem Informasi Manajemen akan semakin meningkatkan penilaian pelanggan terhadap Universitas.

2. Customer value berpengaruh secara signifikan terhadap 
reputasi dalam arti semakin baik penilaian pelanggan akan semakin meningkatkan reputasi Universitas.

3. Sistem Informasi Manajemen tidak berpengaruh secara signifikan terhadap reputasi yang artinya baik atau buruknya Sistem Informasi Manajemen tidak mempengaruhi tinggi rendahnya reputasi Universitas.

4. Semakin baik Sistem Informasi Manajemen akan semakin meningkatkan reputasi Universitas jika penilaian pelanggan terhadap Universitas juga baik.

\section{Saran}

\section{Berdasarkan seluruh pembahasan dan hasil dari kesimpulan penelitian ini maka diajukan saran-saran sebagai berikut:}

1. Pihak Universitas swasta untuk lebih memperhatikan dan meningkatkan Sistem Informasi Manajemen serta lebih meningkatkan penilaian pelanggan agar reputasi Universitas dimata masyarakat lebih baik

2. Bagi peneliti selanjutnya untuk dapat melakukan penelitian pada responden yang lebih luas misalnya pada perusahaan, supaya diperoleh bukti-bukti empirik yang lebih beragam

\section{DAFTAR PUSTAKA}

Barnett, M. L., Jermier, J. M., \& Lafferty, B. A. (2006). Corporate Reputation: The Definitional Landscape.
Corporate Reputation Review, 9(1), 26-38. https://doi.org/10.1057/palgrave .crr.1550012

Beheshtifar, M., \& Korouki, A. (2012). Reputation: An Important Component of Corporations' Value. International Journal of Academic Research in Business and Social Sciences, 3(7), 1520. https://doi.org/10.6007/IJARBS S/v3-i7/6

Hasan, A. (2008). Marketing. Yogyakarta: Medpres.

Kotler, P., \& Gary, A. (2012). Principle of Marketing (14th ed.). USA: Pearson Education.

Kotler, P., \& Keller, L. K. (2008). Manajemen Pemasaran (Edisi Kedua) (Cetakan ke). Jakarta: PT. Indeks.

Mansoor, D., \& Jalal, A. (2011). The Global Business Crisis and Consumer Behavior: Kingdom of Bahrain as a Case Study. International Journal of Business and Management, 6(1), 104-115.

Miles, M. P., \& Covin, J. G. (2000). Environmental Marketing: A Source of Reputational, Competitive, and Financial Advantage. Journal of Business Ethics, Vol. 23(3), 299-311.

Panjaitan, H. (2006). Analisis Respon Konsumen Melalui Sistem Teknologi Informasi, Kualitas Layanan, dan Citra Perguruan Tinggi Swasta di Jawa Timur. Surabaya: Revka Petra Media. 
Parasuraman, A., Zeithaml, V., \& Berry, L. L. (1988). SERVQUAL: a multiple-item scale for measuring consumer perceptions of service quality. Journal of Retailing, 64(1), 1240.

https://doi.org/10.1016/S01482963(99)00084-3

Prajarto, N. (2008). Efektivitas publisitas: menilai reputasi institusi. Jurnal Ilmu Komunikasi, 6(2), 78-84.

Roberts, P. W., \& Dowling, G. R. (2002). Corporate reputation and sustained superior financial performance.

Management Journal, 23(12), 1077-1093.

https://doi.org/10.1002/smj.274

Sweeney, J., \& Soutar, G. (2001). Consumer perceived value: the

development of a multiple item scale. Journal of Retailing, 77(2), 203-220. https://doi.org/10.1016/S00224359(01)00041-0

Too, L., Souchon, A., \& Thirkell, P. (2001). Relationship marketing and customer loyalty in a retail setting: a dyadic exploration. Journal of Marketing Management, (4), 287-319. https://doi.org/10.1362/0267257 012652140

Wijaya, D. (2012). Pemasaran Jasa Pendidikan. Jakarta: Salemba Empat.

Zeithaml, V., Bitner, M. J., \& Gremler, D. (2009). Services Marketing - Integrating Customer Focus Across the Firm. New York: McGraw Hill. 